\title{
GURU SEBAGAI MANAJER KELAS
}

\author{
Diarti Andra Ningsih \\ IAI Muhammadiyah Sinjai \\ diartiandiangkara@gmail.com
}

\begin{abstract}
Abstrak
Kualitas belajar murid dan lulusannya banyak ditentukan oleh keberhasilan seorang guru dalam mengelola kelas. Sehebat apa pun rencana dan tujuan yang ingin dicapai di atas kertas semuanya akan ditentukan dalam ruangan ukuran $6 \times 8$ meter (kelas). Pengelolan kelas dapat terlaksana dengan maksimal apabila guru sebagai manajer dapat melaksanakan komunikasi yang efektif di dalam kelas, hal ini dapat terlakasana apabila guru sebagai manejer mengaktualisasikan tahapan-tahapan manajerial dalam mengimplementasikan pengelolaan kelas. Kemampuan guru dalam melaksanakan pengelolaan kelas merupakan salah satu keterampilan yang dapat menunjang pencapaian tujuan pembelajaran dan sekaligus dapat meningkatkan profesionalisme seorang guru, sehingga diharapkan setiap guru berusaha untuk dapat menguasai masalah yang berkaitan dengan pengelolaan kelas.
\end{abstract}

Kata Kunci: Guru, Manajer Kelas

\section{Pendahuluan}

Sering kali terjadi suasana kelas yang gaduh, bahkan terjadi perkelahian atau perbuatanperbuatan lainnya yang tidak patut dilakukan oleh seorang pelajar tatkala di dalam ruangan tersebut tidak ada guru. Hal ini membutuhkan kiat tertentu dari seorang guru untuk dapat menanggulangi ketidakstabilan di dalam kelas.

Kualitas belajar murid dan lulusannya banyak ditentukan oleh keberhasilan seorang guru dalam mengelola kelas. Sehebat apa pun rencana dan tujuan yang ingin dicapai di atas kertas semuanya akan ditentukan dalam ruangan ukuran 6x8 meter (kelas). Pengelolaan kelas dalam bahasa Inggris diistilahkan sebagai classroom management. Ini berarti, istilah pengelolaan identik dengan manajemen. Pengertian pengelolaan atau manajemen pada umumnya, yaitu kegiatan-kegiatan meliputi perencanaan, pengorganisasian, pengarahan, pengkoordinasian, pengawasan, dan penilaian untuk mencapai tujuan.

Pengelolaan kelas dan pengelolaan pengajaran adalah dua kegiatan yang sangat erat kaitannya tetapi dapat dibedakan karena tujuan yang berbeda, pengelolaan pengajaran (instruction) mencakup semua kegiatan yang secara langsung dimaksudkan untuk mencapai tujuan-tujuan khusus pengajaran, antara lain menyusun rencana pelajaran, memberi informasi, bertanya dan menilai, sedangkan pengelolaan kelas adalah seperangkat kegiatan yang bertujuan menciptakan dan mempertahankan kondisi yang optimal bagi berlangsungnya proses belajar, antara lain pemberian ganjaran (Rohani, 2004: 123).

Proses pendidikan di persekolahan Indonesia, pada umumnya belum menerapkan pembelajaran sampai murid menguasai materi pembelajaran secara tuntas (Depdiknas, 2003 2004: 1-2).

Penanggung jawab proses belajar di dalam kelas terkadang hanya melaksanakan tugasnya sekedar untuk menggugurkan kewajiban tanpa mempertimbangkan tercapai tidaknya tujuan pembelajaran yang telah di tentukan sebelumnya. Hal ini di sebabkan guru tersita perhatiannya untuk mengatur dan mengendalikan perilaku murid yang tidak mendukung tercapainya tujuan pembelajaran. 
Penelitian ini menggunakan metode deskriptif kualitatif yang mendeskripsikan tentang peranan guru sebagai manajer kelas.

\section{Hasil dan Pembahasan}

\subsection{Guru Sebagai Manajer Dalam Pengelolaan Kelas}

Kelas merupakan suatu lingkungan belajar yang diciptakan berdasarkan kesadaran kolektif dari suatu komunitas murid yang relatif memiliki tujuan yang sama. Kesamaan tujuan merupakan kekuatan potensial pengelolan kelas. Pengelolaan kelas mengarah pada peran guru untuk menata pembelajaran. Pengelolaan kelas dalam bahasa Inggris diistilahkan sebagai classroom management. Berdasarkan dari pengertian ini penulis berpendapat bahwa istilah pengelolaan identik dengan manajemen. Pengertian pengelolaan atau manajemen pada umumnya yaitu kegiatan-kegiatan meliputi perencanaan, pengorganisasian, pengarahan, pengkoordinasian, pengawasan, dan penilaian untuk mencapai tujuan.1

Wilford A. Weber mengemukakan, pengelolaan kelas merupakan seperangkat perilaku yang kompleks dimana guru menggunakannya untuk menata dan memelihara kondisi kelas yang akan memampukan para murid mencapai tujuan pembelajaran secara efisien.

Sementara Suharsimi Arikonto seperti yang dikutip oleh pupuh Fathurrohman mengemukakan bahwa pengelolaan kelas adalah suatu usaha yang dilakukan oleh guru untuk membantu menciptakan kondisi belajar yang optimal (Fathurrohman, 2007: 103).

Guru sebagai pengelola kelas (manajer) merupakan seorang pemimpin yang mempunyai peranan yang strategis, yaitu seseorang yang merencanakan kegiatan-kegiatan yang akan dilakukan di kelas, seseorang yang akan mengimplementasikan kegiatan yang direncanakan dengan subjek dan objek, yaitu murid. Seseorang yang menentukan dan mengambil keputusan dengan strategi yang akan digunakan dengan berbagai kegiatan di kelas dan guru pula yang akan menentukan alternatif solusi untuk mengatasi hambatan dan tantangan yang muncul.

Guru sebagai seorang manajer dalam melakukan tugas mengajar di dalam kelas perlu merencanakan dan menentukan pengelolaan kelas seperti apa yang perlu dilakukan dengan memperhatikan kondisi kemampuan belajar murid serta materi pelajaran yang akan diajarkan di kelas tersebut, juga menyusun strategi untuk mengantisipasi apabila hambatan dan tantangan muncul agar proses belajar mengajar tetap dapat berjalan, dan tujuan pembelajaran yang telah ditentukan dapat tercapai.

Pengelolaan kelas dan pengelolaan pengajaran adalah dua kegiatan yang sangat erat kaitan tetapi dapat dibedakan karena tujuan yang berbeda, pengelolaan pengajaran (instruction) mencakup semua kegiatan yang secara langsung dimaksudkan untuk mencapai tujuan-tujuan khusus pengajaran, antara lain menyusun rencana pelajaran, memberi informasi, bertanya dan menilai, sedangkan pengelolaan kelas adalah seperangkat kegiatan yang bertujuan menciptakan dan mempertahankan kondisi yang optimal bagi berlangsungnya proses belajar, antara lain pemberian ganjaran (Rohani, 2004: 123).

Pengelolaan kelas dan pengelolaan pengajaran adalah dua kegiatan yang sangat erat hubungannya tetapi tetap dapat dibedakan dari segi tujuannya. Pengelolaan pengajaran (Instruction) mencakup semua kegiatan yang secara langsung dimaksudkan untuk mencapai tujuan-tujuan khusus pengajaran, sementara pengelolaan kelas menunjukkan kepada kegiatan-kegiatan yang menciptakan dan mempertahankan kondisi yang optimal bagi terjadinya proses belajar, termasuk pembinaan, penghentian tingkah laku murid yang menyelewengkan perhatian kelas. ganjaran (Rohani, 2004: 123124).

Guru sebagai penanggung jawab dalam proses belajar mengajar di kelas dituntut lebih profesional dalam melaksanakan tugasnya sebab guru berada dibawah pengawasan pemerintah daerah

${ }^{1}$ http://coretan rossi. Blogspot.com/2011/04/makalah-profesi-keguruan-karakteristik.html. 
dalam proses pertanggungjawaban hasil proeses belajar yang dilaksanakan dalam kurung waktu tertentu (Mulyasa, 2007: 74-77).

Disamping masalah pertanggungjawaban profesionalisme guru dalam penggelolaan kelas juga akan berdampak terhadap upaya yang dilakukan oleh guru dalam memelihara hubungan baik dengan orang tua murid dan masyarakat sekitarnya untuk membina peran serta dan rasa tanggung jawab bersama terhadap pendidikan yang merupakan salah satu dari beberapa kompetensi yang harus dimiliki oleh guru (Mappanganro,2010: 56-57).

Guru sebagai tokoh utama dalam mendidik dan membimbing murid tidak dapat dipisahkan dari kemampuan guru didalam melaksanakan sistem administrasi dan manajemen pendidikan (Sagala, 2009: 80-81). Menurut pemikiran penulis termasuk juga dalam hal ini keterampilan dalam pengelolaan kelas.

Tanggung jawab guru sebagai salah satu pekerja profesional merupakan bagian yang tidak dapat terpisahkan dari komponen lain adalah guru sebagai pemimpin ( managerial) yang memimpin, mengendalikan diri sendiri, murid dan masyarakat yang terkait berbagai masalah menyangkut upaya pengarahan, pengawasan, pengorganisasian, pengontrolan, dan partisipasi atas program pendidikan yang dilaksanakan (Rostiyah, 1982: 91).

Salah satu upaya yang dapat dilakukan dalam pencapaian tugas dan tanggung jawab guru adalah melakukan proses pembelajaran yang optimal sehingga tujuan pencapaian tugas guru dapat tercapai secara maksimal adalah penerapan penggendalian perilaku murid di dalam kelas, adapun tugas guru yang utama adalah menyempurnakan, membersihkan, menyucikan, serta mengarahkan hati manusia untuk mendekatkan diri kepada Allah swt. (Majid, 2006: 90).

Kesiapan kondisi kemampuan murid yang tidak sama satu dengan yang lain merupakan faktor yang nyata ada di dalam kelas dan tidak bisa dihilangkan. Untuk mengatasi hal tersebut guru sebagai orang yang paling bertanggung jawab dalam menjaga keberlangsungan proses belajar harus berusaha melakukan suatu tindakan preventif. Salah satu hal yang dapat dilakukan oleh guru untuk mengatasi hal tersebut adalah menerapkan pengelolaan kelas secara optimal sehingga murid tetap dapat menerima materi pelajaran serta berprestasi. Pengelolaan kelas memiliki fungsi dan tujuan yang jelas. Tujuan pengelolaan kelas yaitu menciptakan dan menjaga kondisi kelas agar proses belajar mengajar dapat berlangsung dengan baik sesuai dengan sasarannya. Artinya, upaya pengelolaan kelas yang dilakukan oleh guru bertujuan agar semua murid dengan kemampuan yang tidak semuanya sama dapat mengikuti dan menguasai materi pelajaran yang diajarkan guru.

\subsection{Proses Pengelolaan Kelas}

Guru sebagai salah satu kunci keberhasilan sebuah lembaga pendidikan, sebagai sales agent dari lembaga pendidikan berpengaruh terhadap kesan yang timbul dalam masyarakat, baik atau sebaliknya guru dalam memberikan pelayanan dalam proses belajar akan mempengaruhi citra sebuah lembaga pendidikan. Terkait dengan hal tersebut sumber daya guru harus dikembangkan baik melalui pendidikan dan pelatihan maupun kegiatan yang lain sehingga kemampuan profesionalnya dapat meningkat (Alma, 2009: 123).

Tercapai atau tidaknya tujuan pendidikan bukan ditentukan oleh hebatnya seorang menteri atau kepala dinas pendidikan, melainkan ada di tangan seorang gurulah semua beban ditanggung. Setiap proses pengajaran harus direncanakan dan diusahakan oleh guru secara sengaja agar dapat terhindar dari kondisi yang merugikan dan kembali kepada kondisi yang optimal.

Untuk mengelola kelas yang efektif, perlu diperhatikan hal-hal sebagai berikut. Pertama, kesepakatan bersama mengenai kontrak belajar selama berada dalam kelas. Kedua, inventarisasi kelompok murid yang bersifat informal. Bila kelompok ini membawa pengaruh yang negatif, maka harus segera diarahkan ke hal yang positif. Ketiga, memberikan coaching clinic (bimbingan) kepada murid yang apatis, masa bodoh, atau bersikap bermusuhan.

Usaha menciptakan kondisi yang diharapkan, akan efektif apabila memperhatikan hal-hal sebagai berikut: 
1. Diketahui secara tepat faktor-faktor yang dapat menunjang terciptanya kondisi yang menguntungkan dalam proses belajar mengajar.

2. Diketahui masalah yang diperkirakan dan biasanya timbul dan dapat merusak iklim belajar.

3. Dikuasainnya berbagai pendekatan dalam pengelolaan kelas dan diketahui pendekatan yang sesuai denga masalah yang muncul.

Pengelolaan kelas dan pengelolaan pengajaran adalah dua kegiatan yang sangat erat hubungannya tetapi tetap dapat dibedakan dari segi tujuannya. Pengelolaan pengajaran (Instruction) mencakup semua kegiatan yang secara langsung dimaksudkan untuk mencapai tujuan-tujuan khusus pengajaran, sementara pengelolaan kelas menunjukkan kepada kegiatan-kegiatan yang menciptakan dan mempertahankan kondisi yang optimal bagi terjadinya proses belajar, termasuk pembinaan, penghentian tingkah laku murid yang menyelewengkan perhatian di kelas (Alma, 2009: 123-124).

Tindakan pengelolaan kelas adalah tindakan yang dilakukan guru dalam rangka penyediaan kondisi optimal agar proses belajar mengajar berlangsung secara efektif dengan cara menyediakan kondisi baik fisik maupun kondisi sosio-emosional sehingga murid merasakan kenyaman dan keamanan dalam belajar.

Ada beberapa hal yang dapat mempengaruhi pengelolan kelas antara lain kondisi dan situasi belajar mengajar, meliputi kondisi fisik, kondisi sosio-emosinal, kondisi organisasional. Lingkungan fisik tempat belajar mempunyai pengaruh penting terhadap hasil proses belajar, lingkungan fisik yang menguntungkan akan memenuhi syarat minimal dalam mendukung peningkatan intensitas proses perbuatan belajar dan memiliki pengaruh positf terhadap pencapaian tujuan pengajaran. Lingkungan fisik yang dimaksud antara lain sebagai berikut:

a. Ruangan tempat berlangsungnya proses belajar mengajar

b. Pengaturan tempat duduk

c. Ventilasi dan pengaturan cahaya

d. Pengaturan penyimpanan barang-barang (Majid, 2006: 127-129)

Suasana sosio-emosional dalam ruang kelas memiliki pengaruh yang tidak kurang terhadap proses belajar mengajar, kegairahan murid, suasana sosio-emosional yang dimaksud antara lain sebagai berikut:
a. Tipe Kepemimpinan
b. Sikap guru
c. Suara guru
e. Pembinaan Raport (Majid, 2006: 130-131).

Kondisi organisasional yang dimaksud adalah kegiatan rutin yang dilakukan baik pada tingkat kelas maupun pada tingkat sekolah yang telah diatur secara jelas dan telah dikomunikasikan kepada murid secara terbuka akan membentuk pribadi murid. Kegiatan tersebut antara lain sebagai berikut:

a. Penggantian pelajaran

b. Guru yang berhalangan hadir

c. Masalah antar murid

d. Upacara bendera (Majid, 2006: 132-133).

Sebagai pekerja profesional, seorang guru dituntut memiliki kemampuan dalam mendalami kerangka acuan pendekatan pengelolaan kelas sehingga mereka dapat memilih pendekatan yang tepat dalam menangani kasus sesuai dengan hakekat masalah yang muncul.

Ada beberapa konsep tentang pengelolan kelas, sebagian diantaranya tidak dianggap memadai seperti pandangan otoriter yang memandang pengelolan kelas semata-mata sebagai upaya untuk menegakkan tata tertib, atau pandangan permisif yang memusatkan perhatian pada usaha untuk memaksimalkan kebebasan murid. Dalam tulisan ini, penulis tidak akan membahas kedua pandangan tersebut tetapi penulis akan menawarkan pandagan yang dianggap memberi harapan yang positif terhadap pengelolaan kelas, antara lain:
a. Behavior-Modification Approach
b. Socio-Emotional-Climate Approach 


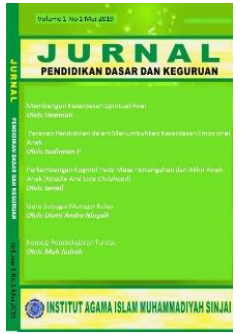

JURNAL

Pendidikan Dasar dan Keguruan

Volume 1, No. 1, 2019

ISSN (print) : 2527-578X

Homepage :

c. Group Processes Approach

d. Eclectic Approach (Majid, 2006: 148-154).

Behavior-Modification pendekatan ini bertujuan untuk membina tingkah laku yang diinginkan guru harus memberi penguatan positif atau penguatan negatif. Sedangkan untuk mengurangi tingkah laku yang tidak dikehendaki, guru mengunakan hukuman. Pendekatan ini bertolak dari psikologi behavioral yang mengemukakan asumsi bahwa semua tingkah laku yang baik maupun yang tidak baik merupakan hasil belajar.

Socio-Emotional-Climate Approach, pendekatan ini menekankan pentingnya guru bersikap tulus di hadapan murid, menerima dan menghargai murid sebagai manusia. Dengan pendekan ini, guru melakukan komunikasi yang efektif dalam pemecahan masalah. Pendekatan ini berlandaskan psikologi klinis dan konseling yang mengasumsikan bahwa proses belajar mengajar yang efektif mempersyaratkan iklim sosio-emosional yang baik, sehingga menumbuhkan hubungan interpersonal yang baik antara guru dengan murid.

Group-Processess Approach, Pendekatan ini didasarkan pada psikologi sosial dan dinamika kelompok dengan asumsi pokok bahwa pengalaman belajar di sekolah berlangsung dalam konteks kelompok sosial, dengan harapan timbal balik tingkah laku antara guru dengan murid dan antar murid itu sendiri.

Eclectic Approach, pendekatan ini adalah perpaduan antara perubahan tingkah laku, penciptaan iklim sosio emosional dan proses kelompok.

Pendekatan perubahan tingkah laku dipilih bila tujuan tindakan pengelolaan yang akan dilakukan adalah untuk menguatkan tingkah laku murid yang baik dan atau untuk menghilangkan tingkah laku murid yang kurang baik. Pendekatan penciptaan iklim sosio-emosional dipergunakan apabila sasaran tindakan pengelolaan adalah peningkatan hubungan antar pribadi guru, murid dan antar murid, sementara pendekatan proses kelompok dianut bila seseorang guru ingin kelompoknya melakukan kegiatan secara produktif.

Sementara Tim Dosen Administrasi Pendidikan Universitas Pendidikan Indonesia mengemukakan bahwa pendekatan dalam melihat permasalahan di kelas antara lain sebagai berikut:

a. Culture.

Culture atau budaya harus dipahami oleh guru, budaya bawaan atau culture haritege yang dimiliki oleh masing-masing murid harus dipahami oleh guru sehingga guru dapat menemukan pendekatan yang sesuai dengan gaya belajar masing-masing murid. Pengembangan budaya organisasi kelas harus mampu memfasilitasi keseluruhan budaya yang melekat pada murid dengan memahami budaya bawaan murid, guru akan mudah dalam menghadapi berbagai masalah yang muncul pada murid (Tim Dosen, 2010: 118).

b. Commitment.

Komitmen adalah sebuah bentuk integrasi secara total dari seseorang terhadap sesuatu atau pekerjaan tertentu dengan melibatkan seluruh aspek yang terdapat pada dirinya. Dalam komitmen terdapat dua unsur yang saling terkait yaitu usaha dan waktu dalam arti bahwa komitmen bukan hanya kata dan perbuatan yang bersifat sementara dan dibuktikan dengan sejumlah usaha yang keras dari seseorang untuk melaksanakan pekerjaan dan mempertahankan kualitas pekerjaan tersebut setta memegang teguh amanah yang sesuai dengan tujuan yang hendak dicapai. (Tim Dosen, 2010: 118).

c. Cummunication.

Guru dapat mengetahui dan memahami masalah yang dihadapi oleh murid dengan adanya komuniukasi yang berjalan secara efektif antara guru dan murid akan mempermudah guru dalam mengidentifikasi masalah, selanjutnya guru dapat menyelesaikan masalah sampai pada akar masalahnya. Terciptanya interaksi yang optimal dalam proses belajar mengajar sangat ditentukan oleh pendekatan yang dilakukan oleh oleh guru dalam rangka pengelolaan kelas. Berbagai pendekatan tersebut antara lain sebagai barikut:

1) Pendekatan kekuasaan, guru mengontrol murid dengan ancaman, sanksi, hukuman dan bentuk disiplin yang ketat dan kaku. 
2) Pendekatan kebebasan guru memberikan suasana dan kondisi belajar yang memungkinkan murid merasa merdeka, bebas, nyaman, penuh tantangan dan harapan dalam melakukan belajar.

3) Pendekatan keseimbangan peran, pendekatan ini dilakukan dengan memberi seperangkat aturan yang disepakati guru dengan murid, aturan itu berkaitan dengan apa yang harus dan apa yang tidak boleh dilakukan oleh murid ataupun guru selama proses belajar berlangsung.

4) Pendekatan pengajaran dalam menerapkan pendekatan ini guru merencanakan dan mengimplementasikan pengajaran dengan baik sehingga dapat mencegah dan menghentikan tingkah laku murid yang kurang mendukung berlangsungnya proses belajar mengajar.

5) Pendekatan suasana emosi dan sosial, pendekatan ini adalah upaya menciptakan iklim atau suasana emosional dan hubungan yang positf dalam kelas.

6) Pendekatan kombinasi, Guru memilih pendekatan yang dianggap tepat dan akurat untuk mengatasi masalah yang muncul di dalam kelas dengan mempertimbangkan berbagai segi dengan memcermati berbagai sisi (Tim Dosen, 2010: 118).

Keterampilan guru dalam menerapkan pendekatan untuk mengatasi masalah yang timbul akibat dari reaksi murid terhadap situasi kelas diharapkan dengan cepat dapat mengembalikan suasana kelas yang kondusif sehingga proses pembelajaran dapat berlanjut dengan normal setelah sebelumnya terjadi masalah yang mengganggu konsentrasi murid.

Kemampuan yang dimiliki guru dalam mengelola kelas pada saat proses belajar mengajar berlangsung akan menciptakan situasai yang memungkinkan murid untuk belajar. Hal ini merupakan titik awal keberhasilan pengajaran karena murid dapat belajar dalam suasana yang wajar dan dalam kondisi yang memotivasi untuk belajar.

Guru sebagai manajer dalam kelas sebaiknya memiliki keterampilan menciptakan situasi yang memungkinkan murid dapat berkomunikasi secara baik. Komunikasi yang dimaksud adalah komunikasi yang berlangsung antara guru dengan murid, murid dengan lingkungan, murid dengan bahan ajar, murid dengan lingkungan maupun murid dengan dirinya sendiri. Hal ini dapat terwujud jika guru sebagai manejer mengaktualisasikan tahapan-tahapan manejerial dalam mengimplementasikan pengelolaan kelas. Adapun implementasi pengelolaan proses belajar mengajar menurut Syaiful Bahri Djamarah seperti yang dikutip oleh Pupuh Fathurrahman antara lain sebagai berikut:

a. Tahapan perencanaan

1) Menetapkan apa yang akan, kapan dan bagaimana cara melakukannya

2) Membatasi sasaran dan menetapkan pelaksanaan kerja untuk mencapai hasil yang maksimal melalui proses penentuan target

3) Mengembangkan alternatif tindakan

4) Mengumpulkan dan menganalisis informasi

5) Mempersiapkan dan mengkomunikasikan rencana-rencana dan keputusan (Fathurrohman, 2007: 111).

b. Pengorganisasian

1) Menyediakan fasilitas, perlengkapan dan tenaga kerja yang diperlukan untuk menyusun kerangka yang efisien dalam melaksanakan rencana-rencana melalui proses penetapan kerja yang diperlukan untuk menyelesaikannya

2) Mengelompokkan kelompok kerja ke dalam struktur organisasi secara teratur

3) Membentuk struktur wewenang dan mekanisme koordinasi

4) Merumuskan, menetapkan metode dan prosedur

5) Memilih, mengadakan latihan dan pendidikan tenaga kerja serta mencari sumber-sumber lain yang diperlukan (Fathurrohman, 2007: 112).

c. Pengarahan

1) Menyusun kerangka waktu dan biaya secara terinci

2) Memprakarsa dan menampilkan pelaksanaan rencana dan pengambilan keputusan

3) Mengeluarkan instruksi-instruksi yang spesifik 
4) Membimbing, memotivasi dan melakukan supervisi (Fathurrohman, 2007: 113).

5) Pengawasan

6) Mengevaluasi pelaksanaan kegiatan

7) Melaporkan penyimpanan dan merumuskan serta menyusun standar-standar dan sasaransasaran tindakan koreksi

8) Menilai pekerjaan dan melakukan tindakan koreksi terhadap penyimpangan-penyimpangan (Fathurrohman, 2007: 113).

Guru dalam melaksanakan tahapan proses pengelolaan kelas diharapkan memiliki pengetahuan dan keterampilan, tahapan demi tahapan harus diterapkan dengan penuh pertimbagan dengan tetap menjadikan murid sebagai sasaran dan tujuan pencapaian proses pembelajaran sebagai hal yang tidak dapat dikesampingkan.

\subsection{Faktor Pendukung dan Penghambat dalam Proses Pengelolaan Kelas}

Proses belajar yang sudah dirancang sedemikian rupa oleh guru terkadang berjalan tidak sesuai dengan yang diharapkan disebabkan oleh berbagai masalah yang dikelompokkan berdasarkan jenisnya. Masalah yang muncul dapat dikelompokkan kedalam dua jenis, yaitu masalah yang muncul secara individu, dan masalah yang muncul karena kelompok.

1. Masalah individu adalah segala permasalahan yang melekat pada perorangan baik karena aktivitasnya yang berlangsung di luar kelas maupun di dalam kelas yang timbul pada saat proses pembelajaran berlangsung karena interaksi dengan murid ataupun guru. Masalah individu dapat timbul apabila terjadi stimulus yang tidak diharapkan dari sikap murid yang lain atau guru bahkan dapat juga bersumber dari materi pelajaran (Fathurrohman, 2007: 113).

2. Masalah kelompok adalah masalah yang dipicu oleh kolektivitas murid yang tidak terorganisir sehingga memicu ketidaksetujuan yang tidak dikomunikasikan secara terbuka yang pada akhirnya menurunkan semangat belajar pada individu tertentu (Fathurrohman, 2007: 117).

Kemampuan guru dalam mengidentifikasi jenis masalah yang muncul di dalam kelas dapat membantu guru untuk mengatasi dan mencari solusi yang tepat untuk menentukan langkah yang dapat menjamin proses belajar di dalam kelas tetap dapat berlangsung.

Ahmad Rohani memaparkan tentang masalah yang dapat timbul dalam pengelolaan kelas seperti yang dikutip dari pendapat Rudolf Dreikurs dan Pearl Cassel mengkalisifikasikan masalah pengelolaan kelas kepada empat kelompok dengan berdasarkan asumsi bahwa semua tingkah laku manusia merupakan upaya pencapaian tujuan pemenuhan keputusan untuk diterima kelompok dan kebutuhan untuk mencapai harga diri. Keempat kelompok tersebut adalah:

a. Tingkah laku yang ingin mendapatkan perhatian orang lain (attention getting behaviors) hal ini dapat dilakukan dengan aktif maupun pasif

b. Tingkah laku yang ingin menunjukkan kekuatan ( power seeking behaviors) hal ini dapat ditunjukkan dengan sikap aktif atau pasif

c. Tingkah laku yang bertujuan menyakiti orang lain ( revenge seeking behaviors) kategori ini umumnya diperlihatkan dengan sikap aktif

d. Peragaan ketidak mampuan, yaitu dalam bentuk sama sekali menolak untuk mencoba melakukan sesuatu (Tim Dosen, $2010: 125$ ).

Kemampuan guru dalam mengidentifikasi tingkah laku murid menyebabkan guru secara bijaksana memberikan tanggapan terhadap perilaku murid di dalam kelas sehingga semua murid merasa mendapat perhatian dan kesempatan yang sama untuk mengaktualisasikan dirinya.

Lois V. Johnson dan Mary A.Bany mengemukakan 6 kategori masalah dalam pengelolan kelas. Masalah-masalah yang dimaksud adalah sebagai berikut:

a. Kelas kurang kohesif hal ini dapat terjadi disebabkan oleh perbedaan suku dan tingkat sosialekonomi

b. Kelas bereaksi negatif terhadap salah seorang anggotanya

c. Memberi ruang gerak kepada anggota yang melanggar norma kelompok 
d. Kelompok cenderung mudah dialihkan perhatiannya

e. Semangat kerja rendah

f. Kelas kurang mampu menyesuaikan diri dengan keadaan baru (Tim Dosen, 2010: 126).

Keenam kategori masalah yang telah dikemukakan dapat muncul pada waktu yang berbarengan, misalnya kelas kurang kohesif menimbulkan reaksi negatif terhadap salah seorang anggota yang disebabkan perbedaan suka atau karena hal yang lain termasuk perbedaan tingkat sosial -ekonomi murid.

Belajar merupakan salah satu kegiatan yang bersifat universal dan multidimensional yang melibatkan guru dan murid dalam situasi yang tidak mudah ditebak, sehingga masalah yang muncul juga kompleks. Made Pidarta membagi masalah pengelolaan kelas kepada masalah yang berkaitan dengan perilaku murid antara lain:

a. Kurangnya kesatuan antara murid karena perbedaan gender, rasa tidak senang, atau persaingan yang tidak sehat.

b. Tidak ada standar perilaku dalam bekerja kelompok, misalnya ribut

c. Terkadang timbul reaksi negatif terhadap anggota kelompok

d. Kelas mentolerir kekeliruan temannya

e. Mudah bereaksi negatif atau merasa terganggu dengan berubahan iklim

f. Moral rendah, permusuhan dan sikap agresif

g. Murid tidak mampu menyesuaikan diri dengan lingkungan yang berubah seperti tugas-tugas tambahan atau ada anggota kelas yang baru (Fathurrohman, 2007: 108-109).

Masih menurut Made sumber masalah tidak hanya bersumber dari murid, guru dapat juga menjadi pihak yang memberikan konstribusi terhadap munculnya masalah di dalam kelas hal ini disebabkan antara lain:

a. Pikiran guru yang sedang kalut

b. Banyaknya pekerjaan yang harus dilakukan oleh guru dalam waktu yang bersamaan

c. Daya introspeksi yang lemah terhadap penampilan fisik

d. Gaya mengajar termasuk pengendalian emosi (Fathurrohman, 2007: 108-109).

Dua kelompok individu yang berinteraksi dalam proses pembelajaran memiliki peluang yang sama dalam memicu timbulnya masalah di dalam kelas. Jika murid sebagai kelompok yang menjadi sasaran proses pembelajaran memicu masalah hal ini dapat diatasi dengan skill yang dimiliki oleh guru. Masalah yang sulit untuk diatasi ketika itu timbul dari guru sebagai manejer di dalam kelas dan pihak yang seharusnya mengatasi masalah yang timbul di dalam kelas.

Pengelolaan kelas yang dilakukan oleh guru sebagai upaya untuk memberikan pelayanan pembelajaran yang sesuai dengan potensi murid sehingga murid dapat belajar dengan baik dan merasa terfasilitasi dari sisi perkembangan fisik dan psikis. Tetapi dalam penyelenggaraan pembelajaran di kelas kadang tidak berlangsung sesuai dengan apa yang telah direncanakan sebelumnya, hal ini di sebabkan oleh beberapa hal, untuk dapat melakukan pengelolaan kelas yang efektif seorang guru harus dapat mengenal beberapa hal yang berkaitan dengan sifat masalah, jenis masalah, dan sumber masalah (Tim Dosen, 2010: 115).

Jika ditinjau dari segi sifanya, masalah dapat diidentifikasi dengan melihat ciri-ciri masalah tersebut meliputi:

a. Perenial, adalah masalah yang melekat dan akan selalu ada ketika terjadi proses interaksi. Pada saat manusia berinteraksi dalam sebuah kelompok terikat, dengan segala perbedaan yang dimiliki dan keinginan yang berbeda akan menimbilkan gesekan dan konflik (Tim Dosen, 2010: 116).

b. Nurturant Effect, atau dampak pengiring artinya bahwa dalam sebuah kegiatan muncul masalah yang tidak di tangani secara tuntas sehingga akan memicu dampak lain sebagai pengikut dari permasalahan tersebut, besar atau kecilnya masalah pengikut yang muncul kemudian sangat tergantung pada bobot bermasalahan awal (Tim Dosen, 2010: 116).

c. Substanstif, masalah dapat dipilah dari sisi pokok yang muncul, permasalahan memiliki karakter yang sesuai dengan substansi problematika dalam interaksi yang terjadi yang dapat memberikan 
gambaran yang pada akhirnya guru dapat mencarikan solusi yang tepat berdasarkan substansi dari masalah yang muncul (Tim Dosen, 2010: 116).

d. Kontekstual, Proses interaksi antara seseorang berlangsung dalam suatu setting tertentu dengan corak yang beragam, situasi sangat berpengaruh terhadap besar kecilnya masalah terkadang juga terkait dengan masalah lain (Tim Dosen, 2010: 116).

Seorang manajer dalam kelas dalam hal ini guru harus dapat mengidentifikasi sifat masalah sehingga guru dapat meminimalisir masalah sekaligus dampak dari masalah yang timbul atau akan timbul dalam proses pembelajaran yang pada akhirnya dapat menciptakan kondisi yang kondusif dalam kelas. Pembelajaran yang terlaksana dengan baik akan menunjang tercapainya tujuan pembelajaran yang maksimal.

Dalam pelaksanaan pengelolan kelas akan ditemukan berbagai faktor penghambat. Hambatan tersebut biasanya datang dari guru, murid, lingkungan keluarga ataupun dipengaruhi oleh faktor fasilitas.

Tidak dapat dipungkiri bahwa guru dapat merupakan faktor penghambat dalam melaksanakan penciptaan suasana yang menguntungkan dalam proses belajar mengajar. Faktor penghambat tersebut dapat berupa antara lain sebagai berikut:
a. Tipe kepemimpinan guru
b. Format belajar mengajar yang monoton
c. Kepribadian guru
d. Pengetahuan guru
e. Pemahaman guru tentang murid (Tim Dosen, 2010: 156).

Ibrahim Bafadal mengemukakan, bahwa dalam proses peningkatan mutu pendidikan diperlukan guru baik secara individu maupun kolaboratif untuk melakukan suatu pengubahan "status qao" agar pendidikan dan pembelajaran menjadi lebih berkualitas (Bafadal, 2008: 3).

Faktor lain yang dapat merupakan hambatan dalam pengelolaan kelas adalah faktor murid. Murid dalam pengelolaan kelas dapat dianggap sebagai seorang individu dalam suatu masyarakat kecil yaitu kelas dan sekolah.

Kekurangsadaran murid dalam memenuhi tugas dan haknya sebagai anggota suatu kelas atau suatu sekolah dapat merupakan faktor utama penyebab masalah pengelolaan kelas.

Tingkah laku murid di dalam kelas merupakan pencerminan keadaan keluarganya. Kebiasaan yang kurang baik di lingkungan keluarga seperti tidak tertib, tidak patuh pada disiplin, kebebasan yang berlebihan atau terlampau dikekang merupakan latar belakang yang menyebabkan murid melanggar disiplin di kelas. Tuntutan di kelas atau sekolah yang berbeda dengan kondisi kehidupan keluarga akan merupakan kesulitan tersendiri bagi murid untuk menyesuaikan diri. (Tim Dosen, 2010: 159).

Sarana dan prasana dalam pencapaian tujuan sesuatu merupakan faktor yang menetukan. Fasilitas yang tidak memadai merupakan penghambat dalam pengelolaan kelas, faktor tersebut meliputi antara lain:

a. Jumlah murid dalam kelas

b. Besar ruangan kelas

c. Ketersediaan alat (Tim Dosen, 2010: 160).

Faktor guru, murid, lingkungan keluarga, dan fasilitas merupakan faktor yang harus tetap diperhitungkan dalam menangani masalah pengelolaan kelas.

\section{Simpulan}

Pengelolaan kelas dalam bahasa Inggris diistilahkan sebagai classroom management. Ini berarti, istilah pengelolaan identik dengan manajemen pengelolaan kelas adalah seperangkat kegiatan yang bertujuan menciptakan dan mempertahankan kondisi yang optimal bagi berlangsungnya proses belajar. 


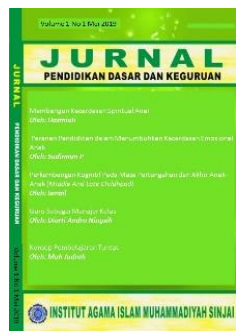

JURNAL

Pendidikan Dasar dan Keguruan

Volume 1, No. 1, 2019

ISSN (print) : 2527-578X

Homepage :

Pengelolan kelas dapat terlaksana dengan maksimal apabila guru sebagai manajer dapat melaksanakan komunikasi yang efektif di dalam kelas. Hal ini dapat terlakasana apabila guru sebagai manejer mengaktualisasikan tahapan-tahapan manajerial dalam mengimplementasikan pengelolaan kelas.

Pengelolaan kelas yang dilakukan oleh guru sebagai upaya untuk memberikan pelayanan dalam proses belajar yang sudah dirancang sedemikian rupa oleh guru terkadang berjalan tidak sesuai dengan yang diharapkan disebabkan oleh berbagai masalah. Kemampuan guru dalam mengidentifikasi jenis masalah yang muncul di dalam kelas dapat membantu guru untuk mengatasi dan mencari solusi yang tepat

\section{Daftar Pustaka}

Alma, Buchari, Guru profesional Menguasai Metode dan Terampil Mengajar. Bandung: Alfabeta, 2009.

Bafadal, Ibrahim. Peningkatan Profesionalisme Guru Sekolah Dasar. Jakarta: PT Bumi Aksara, 2008.

Depdiknas. Pedoman Pembelajaran Tuntas ( mastery Learning ). Jakarta: 20032004.

Fathurrohman, Pupuh M. Sobry Sutikno. Strategi Belajar Mengajar, Strategi Mewujudkan Pembelajaran Bermakna Melalui Penanaman Konsep Umum \&Konsep Islami. Cet.I; Bandung: PT. Refika Aditama, 2007.

http://coretan rossi. Blogspot.com/2011/04/makalah-profesi-keguruan-karakteristik.html.

Majid, Abdul dan Jusuf Mudzakkir. Ilmu Pendidikan Islam. Jakarta: Kencana. 2006.

Mappanganro. Pemilikan Kompetensi Guru. Makassar: Alauddin Press. Cet. I; 2010.

Mulyasa, E. Manajemen Berbasis Sekolah, konsep, Strategi, dan Implementasi. Bandung: PT Remaja Rosda karya, Cet;XI . 2007.

Rohani, Ahmad. Pengelolaan Pengajaran. Cet. II; Jakarta: PT. Renika Cipta, 2004.

Rostiyah, NK,. Masalah-masalah Ilmu Keguruan. Jakarta: Bina Aksara. 1982.

Sagala, Syaiful. Kemampuan Profesional Guru dan Tenaga Kependidikan. Bandung: ALVABETA, Cet;II, 2009.

Tim Dosen Administrasi Pendidikan Universitas Pendidikan Indonesia. Manajemen Pendidikan. Cet. II;Bandung Alfabeta.2010. 